DOI https://doi.org/10.18551/rjoas.2018-04.05

\title{
INFRASTRUCTURE EXPENDITURE AND POVERTY REDUCTION IN INDONESIA
}

\author{
Arma Nur Ambia* \\ Master's Degree Program in Public Administration, Faculty of Administrative Science, \\ University of Brawijaya, Indonesia \\ Noor Irwan, Sujarwoto \\ Faculty of Administrative Science, Universitas Brawijaya, Indonesia \\ *E-mail: ambiaarma.aa@gmail.com
}

\begin{abstract}
The purpose of this paper is to examine the impact of infrastructure expenditure to education, health and roads on poverty reduction in Indonesia. The relationship of both variables controlled through other determinants such as locally generated revenue, gross regional domestic product, population and good governance index. Using Data Panel in Indonesia years 2006 up to 2015, were analyzed using an econometric model with fixed effect regression. The results show that infrastructure expenditure to education and health have a negative influence significantly to poverty reduction, while road infrastructure expenditure has not significant impact on poverty reduction in Indonesia.
\end{abstract}

\section{KEY WORDS}

Infrastructure expenditure, poverty reduction, good governance, education, people health.

Poverty is classified as a serious issue of concern to the world. This fact marked by the election of poverty reduction as the primary goal of SDGs (sustainable development Goals). Through a study conducted by Roser and Ospina (2018), it was noted that approximately 746 million people in the world live in extreme poverty in 2013. And then decreased became as many as 705 million people in 2015 . They are not able to meet some of their basic needs such as education, health, access to infrastructure, so they become unproductive resources.

Indonesia is one of the developing countries that have a problem of extreme poverty that has not been solved until now. Solihin (2014: 8) in his book "Implementation of Poverty Reduction Policy" mapped the profile of Indonesia's poor in 2007. This mapping is to identify a state of extreme poverty. Every 100 residents of Indonesia, 44 people do not have access to clean water; 49 people do not have access to adequate sanitation; 49 people not pass the primary school; 11 people are illiterate; 42 people live in villages that are not junior high school; 36 people live in villages without telephone connections; 25 children under five are malnourished and 82 babies were born handled by unskilled birth attendants.

The poverty rate in Indonesia is fluctuating over ten years. However, the trend of poverty in Indonesia has decreased significantly. Since the economic crisis in mid-1997 led to as many as 49.5 million people into the poverty line. Until 2015, the number of poor people in Indonesia reached 28.76 million (Kuncoro, 2010; CBS, 2015).

Overcoming the problem of poverty, the Indonesian government has issued various policies. One of them is to prioritize the development of infrastructure in order to reduce the inequality between urban and rural areas in the hope of reducing poverty. As we know that about $65 \%$ of Indonesia's population lives in rural areas and the rest live in urban areas (CBS, 2010).

Rural areas are generally characterized by the social and economic backwardness such as low levels of education, unproductive, malnutrition, limited employment, and low access to capital (Rustanto, 2015). While urban is identical with more adequate facilities like educational facilities, health, and access to basic infrastructure and the availability of employment. Therefore, the priority of this infrastructure development policy that set by the Indonesian government aims to provide the same facilities in each region. 
World Bank (2004) said that in supporting the poverty reduction programs, it is necessary to take several steps related to infrastructure, namely: 1) improvement of roads and electricity facilities; 2) improvement of health level; and 3) improvement to the quality of education. thus, by putting special attention to infrastructure development such as roads, access to clean water, the provision of educational infrastructure, health infrastructure and other infrastructure are believed to help reduce poverty (Ali and Pernia, 2003; Seetanah, et al, 2009; Rusinarith, 2010).

The relationship between infrastructure and poverty has also been demonstrated by Marinho et al., (2017) in his research in Brazil. The results show that the infrastructure has affected the temporal trajectory in Brazil, which means there is a change of situation after the infrastructure improvements by using an index that consisting of the transportation, energy and mineral resources, communication and health, sanitation, gross domestic product per capita and education to reduce poverty in Brazil.

The policy of infrastructure development becomes the main focus in reducing poverty as stated in NAWACITA, and types of infrastructure that become priorities are clarified in the Presidential Regulation Number 75 the year 2014 on Acceleration of Infrastructure Provision priority which has been converted into the Presidential Regulation No. 122 the year 2016. Types the infrastructure is transportation, roads, irrigation, drinking water, wastewater, solid waste facilities, telecommunication and informatics infrastructure, electricity, oil and gas, educational facilities, health infrastructure, regional infrastructure and tourism infrastructure.

The commitment to fulfill of infrastructure facilities in each region is reflected in the number of infrastructure budget issued by the government each year. In 2010 the budget spent on infrastructure amounting to Rp 86 trillion and continues to rise until 2016 became Rp 317.1 trillion (databoks, 2016).

The budget is financial use activity plan that embodies the estimates spending that are arranged in a proposal for a specific period of time. After being drafted and then authorized to finance the development estimate. So the budget for infrastructure development is a government expenditure plan to realize infrastructure development in order to assist the community in fulfilling their life needs.

Mardiasmo (2005: 65) points out the importance of a budget is due to: First, the budget is a tool that is used to direct economic development, to ensure the sustainability and improve the quality of people's lives. Therefore, the actions of poverty reduction, the budget is used for designing and estimating activities or the allocation of public expenditure on community infrastructure. Secondly, the budget is needed because of the needs and desires of citizens who are not of limited value and continue to grow. So that through the budget, the government can control and limit the expenditure to build infrastructure is a top priority community needs such as access to education, access to health care, access roads, access to electricity and telecommunications access. Third, the budget required to declare that the government was accountable to the people. Then, in order to realize the welfare of society, after the development plan, the budget becomes a proof that the government cares and has to perform its role as a function of the allocation of infrastructure that aims to meet the needs of the life of its citizens.

This paper aims to analyze the relationship between the amount of budget for infrastructure issued by the government with the decrease of the number of people in poverty in Indonesia. Using indicators of the amount of the infrastructure budget to the type of infrastructure that consists of social infrastructure: education and health, and economic infrastructure is the availability of roads (World Bank, 1994; Familioni, 2004: 20).

Kartasasmita (1996: 240) states that poverty is caused by lack of education a person so that the person does not have the skills, personal development, and confidence. And Jhinghan (2000) added that the cause of a person in a poor state due to lack of adequate infrastructure for education, causing a lot of people who are not educated and do not have the skills. In fact, these skills will be useful for a country because of his ability to absorb modern technology and to develop the capacity to create growth and sustainable development (Todaro, 2011).

The importance of the budget for infrastructure in reducing poverty has been proven by 
numerous studies. Fan, Hazell, and Thorat (2000) in India to prove that any government expenditure on education, the effect is much infrastructure on poverty in the countryside. Every one million Rupee issued by the government, it will increase forty-one people to rise to the base of the poverty line.

Fan, Zhang, and Zhang (2002) in China, proved that expenditure on rural education infrastructure has contributed to poverty reduction. For every government expenditure of 10,000 yuan then about 9 (nine) people will be out of poverty line. Fan, Jitssuchon, and Methakunnavut (2004) proved that government expenditure on education infrastructure in Thailand is very influential on poverty, where every million Baths spent, the poor in Thailand will be reduced by 21 . This proves that budgetary support for infrastructure for access to education is needed, especially in rural areas.

World Bank (2004) argued that in order to realize and support the implementation of poverty reduction programs, one of them is needed to improve access to health services. Suitable empirical studies include by Prasetya et al (2012) saying that government expenditure on health significantly affects the number of poor people in rural areas.

Fan, Hazell, and Thorat (2000) have examined the link between public expenditure for health and for roads with poverty. That every one million rupees spent will raise 18 poor people to the poverty line. By increasing about 100 billion rupees, the poverty rate will decrease by $0.65 \%$. Or with every one million rupees in spending on road infrastructure in India, it will lift as many as 124 poor people out of poverty line.

Fan, Zhang and Zhang (2002) also prove for road infrastructure in China, that by increasing government spending for the development of good and high-quality roads such as roads connecting major industrial centers in coastal and rural areas have had an effect on poverty reduction. Every 10,000 yuan has been upgraded to 3.2 of poor people up to the poverty line.

Similarly, research by Fan, Jitsuchon, and Methakunnavut (2004) in Thailand. The results show that there is an influence with increased expenditure on road infrastructure on poverty reduction. Where every one million Bhats issued by the Thai government for the development of quality roads has been able to lift as many as 107 poot people into the poverty line.

Study of Hastuti (2016) also proves that the larger the paved area (good or quality) then the opportunity for non-poor people in the region increases. Because of the access road has an important role in the economic, social, cultural, environmental, political, defense and security, as well as used for the welfare of the people. The road is also the distribution infrastructure of goods and services as the lifeblood of the community. So with the availability of access roads can easily cause people to perform activities and reach to the center of the economy, smoothen the course of productivity of goods and services and facilitate people reach their daily needs. Therefore, the budget on infrastructure development is needed in order to reduce poverty.

Basically, the budget issued by the government, in order to build the infrastructure can reduce poverty if the budget is managed on target. That is, it takes the role of government in the distribution of the budget in the context of infrastructure development. Due to poverty reduction not only by looking at the growth of the economy but also their need for good governance in order to allocate funds effectively and efficiently so as to achieve the purpose of access to infrastructure for public services.

Basically, the budget spent by the government in order to build infrastructure can reduce poverty if the infrastructure expenditure is properly managed. Means that it takes the role of government in the budget disbursement in the framework of infrastructure development. Because in alleviating poverty not only by looking at economic growth, but also need a good governance in order to allocate the budget effectively and efficiently. So the goals of infrastructure access service for the community can be achieved.

The existence of good governance will encourage the achievement of the target of allocating funding that was issued to create a service to the community in the provision of infrastructure, good educational infrastructure, health, and roads. Because, in the absence of good governance, funds for poverty alleviation will not be realized. This can occur if the lack 
of transparency on the use of a number of the budget.

Turkewitz (2001) has reviewed the relationship of good governance principles in its activities to manage the budget for development. Through the identification of the achievements of several indicators with an establishment, he concluded that there is a close connection to the principle of good governance. The more effective a rule, the lower the infant mortality rate. The lower the level of corruption in the government bureaucracy, the higher the level of adult literacy.

Rajkumar and Swaroop (2008) analyzed the relationship between public spending by the government and the resulting outcomes. His study found that government expenditure to infrastructure in the health sector has a very strong negative impact on child mortality in countries that have good governance. This means that the higher the expenditure incurred by good governance, it will reduce child mortality rate significantly. Additionally, Rajkumar and Swaroop also stated that the lower the level of corruption or the higher quality of the bureaucracy, the expenditure infrastructure on health will be more effective in reducing child mortality. Conversely, they also found that countries with high levels of corruption and highly inefficient bureaucratic circumstance caused expenditure on health to be ineffective as well. So is the same case with education. The higher government expenditure on education will lead to more effective in improving the educational attainment with good governance. While countries with bad governance have lower levels of education (Gupta et al., 2000).

Kaufmann, Kraay, and Zoidolabaton (1999) also conducted an empirical study and found that good governance is essential in a country's economic performance. In the standard devaluation increase on one of the indicators of good governance, led to a decrease of two and a half to fourfold reduction in infant mortality rate. Likewise, with Sumartono, Suryahadi, Arifianto (2004) argued that without good governance, any funds budgeted for poverty alleviation cannot be used properly. Because of the lack of transparency and rampant corruption practices. The reason is that corruption causes misused budget and the budget allocation for poverty reduction diverted to other projects more in line with the interests of the authority holders.

\section{METHODS OF RESEARCH}

Data description. This paper was conducted to see how the relationship between education, health and road infrastructure expenditure to reduce poverty in Indonesia. Seeing this relationship is controlled by a factor of economic growth through local revenues and the value of the regional gross domestic product; factor index of good governance; and the population of the district and cities in Indonesia. The data in this paper is used secondary data, with a cross-section which is 512 regencies and cities in Indonesia, and time-series from 2006 to 2015.

Measurement of poverty in this study using the approach of the basic needs conducted CBS (2016). That is someone who cannot meet their basic needs such as food, clothing, housing, education, and health.

Table 1 - Variables, definitions and Sources

\begin{tabular}{|c|c|c|}
\hline Variables & Definition & Sources \\
\hline Poverty & The amount of poor people (Million people) & Central Bureau of Statistics Indonesia \\
\hline $\begin{array}{l}\text { Education } \\
\text { (IEE) }\end{array}$ & Infrastructure expenditure for education (Rp Billion) & $\begin{array}{l}\text { Regional financial information system at the } \\
\text { Ministry of finance }\end{array}$ \\
\hline Health (IEH) & Infrastructure expenditure for health (Rp Billion) & $\begin{array}{l}\text { Regional financial information system at the } \\
\text { Ministry of finance }\end{array}$ \\
\hline Roads (IER) & $\begin{array}{l}\text { Infrastructure expenditure for roads from special } \\
\text { allocation funds (Rp Billion) }\end{array}$ & $\begin{array}{l}\text { Regional financial information system at the } \\
\text { Ministry of finance }\end{array}$ \\
\hline $\begin{array}{l}\text { Populations } \\
\text { (TP) }\end{array}$ & Total of Populations in Indonesia ( in log) & Central Bureau of Statistics Indonesia \\
\hline PAD & $\begin{array}{l}\text { Total of locally generated revenue at distric and city in } \\
\text { Indonesia (in log) }\end{array}$ & $\begin{array}{l}\text { regional financial information system at the } \\
\text { Ministry of finance }\end{array}$ \\
\hline GDP & $\begin{array}{l}\text { Gross regional domestic product at distric and city in } \\
\text { Indonesia (in log) }\end{array}$ & Central Bureau of statistics Indonesia \\
\hline GGI & Good governance index (in percentage) & Indonesia Good Governenance Index \\
\hline
\end{tabular}


Descriptive analysis. This paper presents a descriptive analysis to describe the trend of the poverty level, the expenditure of infrastructure to education, health, and roads in Indonesia years 2006 to 2015. An analysis of this description will show the development of each variable in the form of graphs based on rural and urban areas.

Correlation analysis. This paper will do the Pearson correlation which will be demonstrated through scatter plot using Spss software version21. Correlation analysis aims to demonstrate the pattern of relationship lines formed on each of the independent variables on the dependent variable, which would explain the following relationship:

- Correlation infrastructure expenditure education with poverty;

- Correlation infrastructure expenditure health to poverty;

- Correlation infrastructure expenditure for road and poverty.

Fixed effect analysis. Fixed effect is one of panel data regression analysis. That is combination of time series data with cross-section data. The fixed effect panel data model assumes a fundamental difference between the areas can be accommodated through the intercept differences, but inter-timed intercepts are the same. The fixed effect means that the regression coefficient (slope) remains the unit analysis and inter-timing. The panel data regression model with fixed effects model (FEM) is when ai treated as a fixed parameters, but vaies between $\mathrm{I}=1,2,3, \ldots \mathrm{N}$. This model is used when the securities unit of analysis and the effects of time correlated with Xit (infrastructure budget to $i$ and at time to $t$ ) or has a pattern that is not randomized (random). This assumption makes the error component of the unit analysis and time effects can be part of the intercept. FEM generally occurs when $\mathrm{N}$ is relatively small and $\mathrm{T}$ is relatively large. Equation of Fixed effect regression model is:

$$
Y_{i t}=\beta_{01}+\beta_{1} X_{1 i t}+\beta_{2} X_{2 i t}+\beta_{3} X_{3 i t}+e_{i t}
$$

Where: $i=$ district $/$ city; $t=$ time; $\mathrm{Y}_{\mathrm{it}}=$ value analysis of poverty in the $\mathrm{i}$-th unit in year $\mathrm{t}$; $\mathrm{X}_{1 \mathrm{it}}=$ the value of education infrastructure budget on the $\mathrm{i}$-th unit of analysis in year-to-t; $\mathrm{X}_{2 \mathrm{it}}=$ the value of the health infrastructure budget analysis of the $\mathrm{i}$-th unit in year $\mathrm{t} ; \mathrm{X}_{3 \mathrm{it}}=$ value of road infrastructure budget on the unit of analysis to-i in year $t ; \beta=$ coefficient; and $e_{i t}=$ confounders (error).

Based on the equation of the model, can be formulated equation for this study, namely:

$$
\begin{gathered}
\text { Poverty }=\beta_{0}+\beta_{1} I E E_{i t}+\beta_{2} I E H_{i t}+\beta_{3} I E R_{i t}+\beta_{4} G G l_{i t}+\left.\beta_{5} I E E^{*} G G\right|_{i t}+\left.\beta_{6} I E H^{*} G G\right|_{i t}+ \\
\beta_{7} I E R^{*} G G l_{i t}+\beta_{8} P_{A D}+\beta_{9} G D P_{i t}+\beta_{10} T_{i t}+e_{i t}
\end{gathered}
$$

\section{RESULTS AND DISCUSSION}

Trends of Infrastructure expenditure and poverty in Indonesia, years 2006-2015. The Indonesian government has sought to reduce poverty, one of them through increased the expenditure for infrastructure. Infrastructure expenditure such as education, health and roads become priorities underway which aims to provide services to the community in the form of infrastructure facilities. So they can easily meet their basic needs. Government expenditure on infrastructure development and poverty reduction for the years 2006-2015 are shown in figure 1.

Figure 1 shows the development of infrastructure expenditure for education, health and roads during the years 2006 to 2015. Each expenditure is categorized in rural and urban areas. The results show that over the past 10 years, expenditure for education and health infrastructure has been increased annually, both in rural and urban areas. However, the expenditure of road infrastructure has fluctuated, namely the increase and decrease in both rural and urban areas.

Infrastructure expenditure for education, health, and roads has been allocated more to rural areas than urban areas. For education, rural accept the budget as much as Rp 41.61 trillion, while urban areas were only Rp 9.92 trillion. Until 2015, the budget for rural areas amounted to $R p 150.14$ trillion, while in urban areas it was only Rp 32.5 trillion. The increase in the number of the budget in the countryside for 10 years was Rp 108.53 trillion, while in 
urban areas the increase for 10 years was 22.58 trillion. This means that the total budget of the education infrastructure for 10 -year, amounting to $80 \%$ is allocated in rural areas and $20 \%$ is allocated in urban areas. For health, rural allocated Rp 10.9 trillion in 2006 to Rp 50.79 trillion in 2015 . So the increase that occurred was $\mathrm{Rp} 39.89$ trillion. As for the allocation in urban areas amounted to Rp 2.74 trillion in 2006 and Rp 11.94 trillion in 2015. This means that for urban areas the increase in the period of 10 years is Rp 9.2 trillion. As with the infrastructure expenditure for education, $80 \%$ of the total of infrastructure expenditure for health is allocated to rural areas and the remaining $20 \%$ is allocated to urban areas.

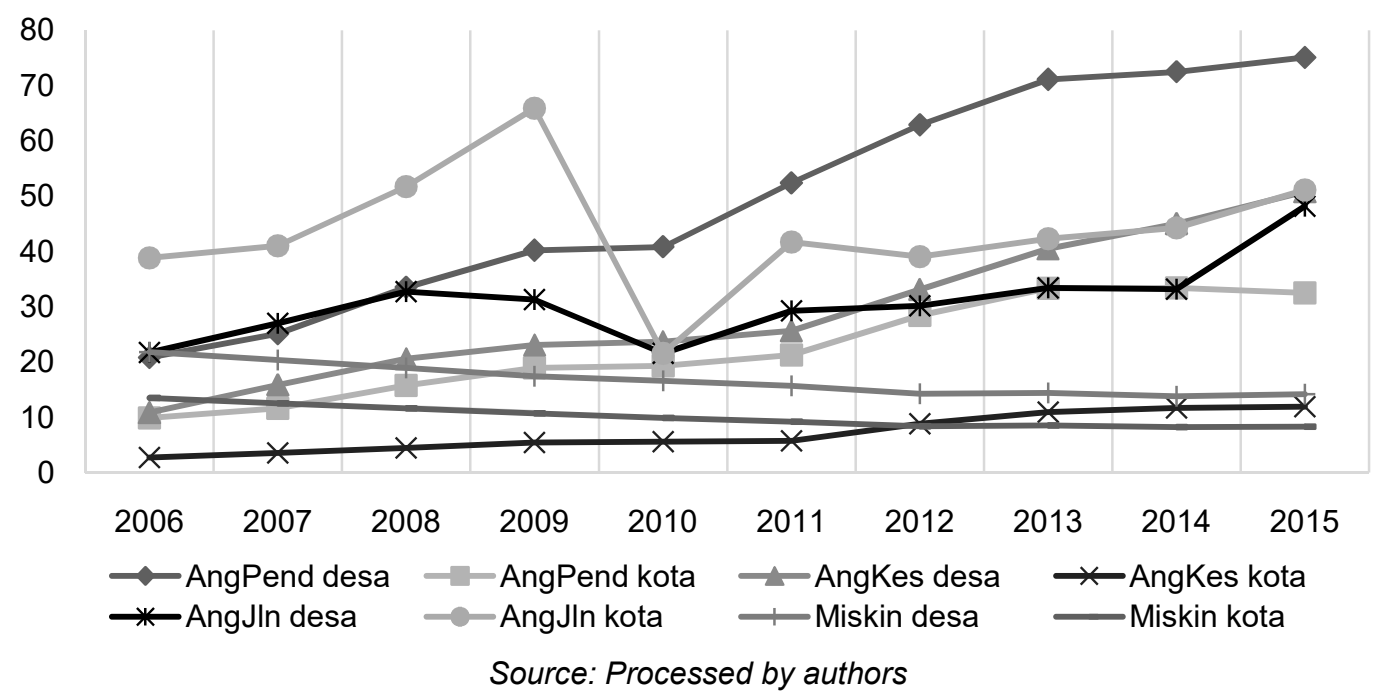

Figure 1 - Trend of Infrastructure Expenditure and Poverty in Indonesia, years 2006-2015

In contrast to expenditure on education and health, infrastructure expenditure for roads is fluctuating and proportion for rural and urban areas is different every year. In 2006 the proportion given to rural areas was $85 \%$ of the total and for urban areas only $15 \%$. In 2007 the proportion of $87 \%$ of rural and urban areas only $13 \%$. In 2008 the proportion of $87 \%$ rural and $13 \%$ urban. In 2009 the proportion of rural areas by $83 \%$ while only $17 \%$ urban. In 2010 the proportion of rural areas by 91\% while for urban only 9\%. In 2011 and 2012 the proportion of rural dropped to only $88 \%$ and urban by $12 \%$. In 2013 and 2014 the proportion of $89 \%$ for rural and urban $11 \%$, and in 2015 amounted to $90.5 \%$, while for urban areas it was $9.5 \%$.

The ratio of poverty in Indonesia has also been displayed in Figure 1. It shows that distribution of poverty in Indonesia is more prevalent in rural than urban areas. This happens because Indonesia has more villages than cities and about $65 \%$ of Indonesia's population live in rural areas and the rest in urban areas. Another thing that causes a higher rural poverty is because the countryside is characterized as more areas lagging behind urban areas in the economic, social, education and health as well as lagging behind in infrastructure.

The trend of poverty for years 2006 to 2015 under the provisions of the Central Bureau of Statistics Indonesia have experienced a decline in both rural and urban. Over the ten years, the rural poverty has decreased by $7.6 \%$ while urban areas have decreased by $5.2 \%$. Rural areas have a more poverty reduction than urban areas. This fact is in line with the expenditure of more infrastructure for rural than urban. This justifies, that by providing a larger budget for rural areas can able to reduce poverty is greater as well.

This correlation is done by Pearson correlation method through SPSS application version 21. The objective of doing this correlation test is to measure the strength as well as to determine the direction of a linear relationship between two variables. That is, the correlation is not to pay attention to their causality, and causality, which are affected and which affect. So that both variables may act as a variable $X$ and variable $Y$.

Infrastructure Expenditure to Education with Poverty. Figure 2 displays a pattern 
of relationships that occur in the development of infrastructure expenditure for education with the development of poverty in the counties and cities in Indonesia in 2006-2015. The results suggest that the confidence level on the graph only $99 \%$ with $\alpha=0.01$ (1\%) and the coefficient of determinasi is 0.26 . This means that $26 \%$ of poverty can be explained by a number of educational infrastructure expenditure. Then the Pearson correlation results for 0.509. This means that there is a positive relationship between expenditure on education infrastructure with significant poverty represented by the same with $0.000<0.05$. However, the level of relations held by these two variables is enough. Thus, the relationship contained in this variable is the bigger the infrastructure expenditure for educational issues, the higher the poverty rate in Indonesia.

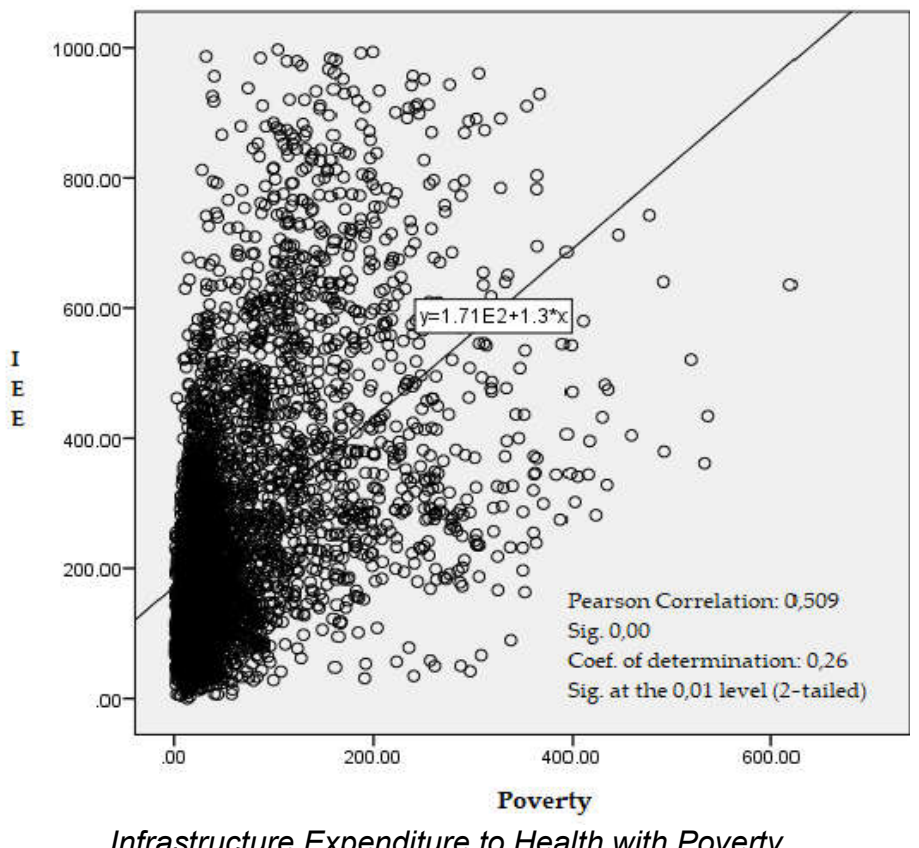

Figure 2 - Correlations between infrastructure expenditure on education with poverty

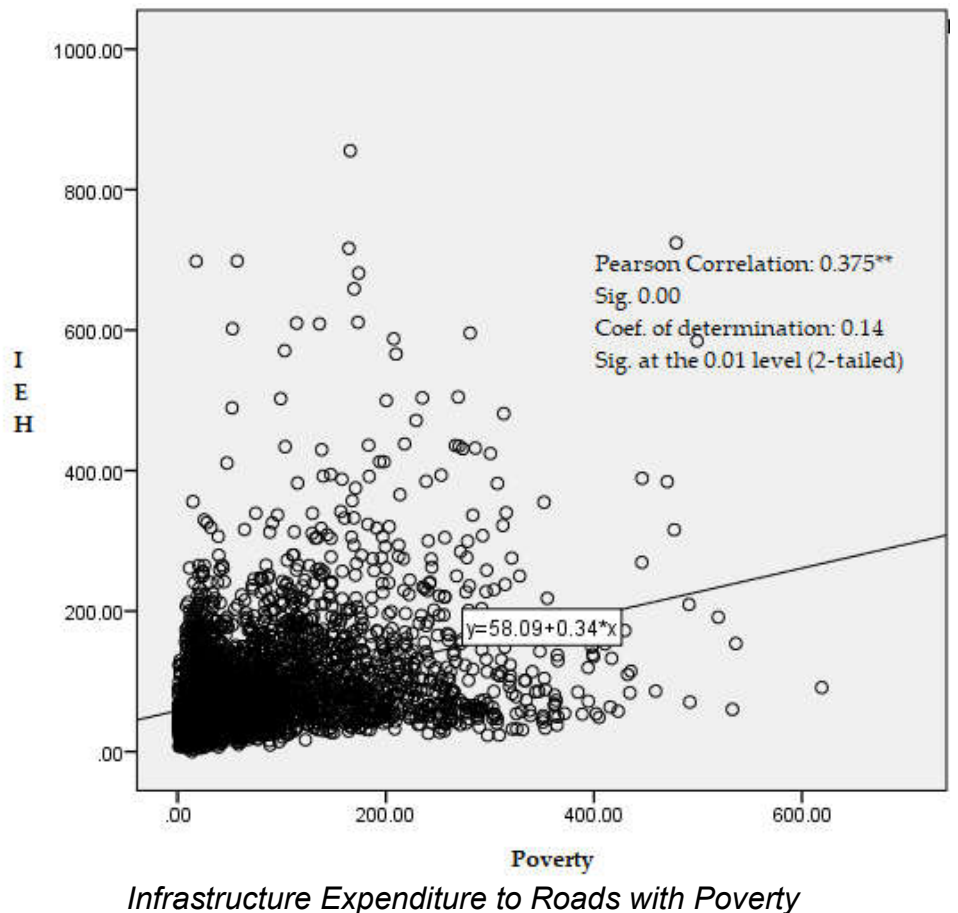

Figure 3 - Correlations between infrastructure expenditure on health with poverty 
The pattern of lingkages between infrastructure expenditure for health and poverty is shown in figure 3 and shows a positive relationship.

The linear line indicates that the two variable contains the value that is directly proportional. This means that the higher the number issued health infrastructure, the higher the poverty. The confidence level of thus correlation is $99 \% \%$ with $\alpha=0.01(1 \%)$. While, the coefficient of determination is 0.14 . This means that only $14 \%$ of poverty can be explained by the amount of infrastructure expenditure for health. Then the results of Pearson correlation is 0.375 . This means that there is a positive relationship between the expenditure of infrastructure for education with poverty indicated by significant equal to $0.00<0.05$. Just as the level of infrastructure expenditure relates to education, the extent to which this variable of health infrastructure expenditure on poverty is sufficient.

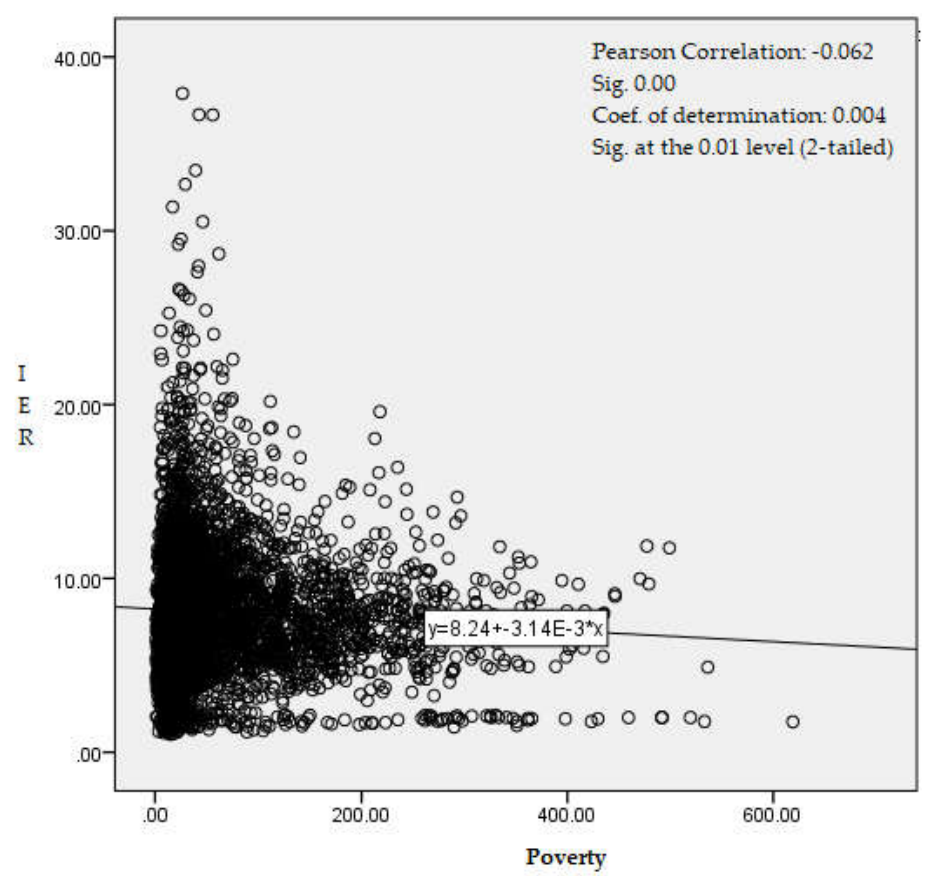

Figure 4 - Correlations between infrastructure expenditure on roads with poverty

Figure 4 shows a pattern of relationships that occur on infrastructure expenditure for education and poverty in the counties and cities in Indonesia in 2006-2015. The results suggest that the confidence level on the graph is $99 \%$ with $\alpha=0.01(1 \%)$. While the coefficient of determination is 0.004 . This means that the level of incredulity variable expenditure for road infrastructure is very low to be able to explain the variables of poverty. Then the results of Pearson correlation of -0063 . This means that there is a negative relationship between expenditure on road infrastructure with significant poverty represented by the same with $0.00<0.05$. Thus, an explanation of the two variables is the higher the expenditure of road infrastructure, the poverty in Indonesia will be lower. However, the level of relationship both variables is very low. With the very low level of trust and level of relationships, the variables of infrastructure expenditure for roads can be at virtually unrelated values.

Analysis Econometric models. This section identifies the relationship between poverty and infrastructure expenditure for education, health, and roads that are controlled by some other determining factors such as local revenue, gross regional domestic product, population and good governance index. Based on the test results chow and Hausman test, the exact method used in this research is the analysis of the fixed effect. The result of the influence of the independent variables and the dependent variables are shown in Table A1.

This section identifies the relationship between poverty and infrastructure expenditure for education, health, and road that are controlled by some other determining factors such as 
local revenue, gross regional domestic product, population and good governance index. Based on the results from Chow test and Hausman test, the exact method used in this research is the analysis of the fixed effect. The result of the influence of the independent variables and the dependent variables are shown in Table 1.

Model 1 shows the influence of the infrastructure budget to poverty. The results suggest that only the infrastructure expenditure for education has a significant negative effect. This is indicated by the coefficient value of -0.084824 with a probability of 0.000 (less than $5 \%$ ). This means that every $1 \%$ of the education infrastructure expenditure increases, poverty will decrease by $0.085 \%$. While the expenditure of health and road infrastructure has no significant effect on poverty. This is proven by the probability value of both variables is equal to 0.1430 and 0.6511 (greater than $5 \%$ ).

Model 2 shows the influence of infrastructure budget on poverty with the existence of control variable that is the index of good governance. With controls of good governance index causing the coefficient value of infrastructure expenditure variable decreased. In education infrastructure budget has a coefficient value of -0.81445 with a probability of 0.0000 (less than 5\%). This indicates that the presence of factors governance, education infrastructure budget has a significant impact on poverty. While the health and road infrastructure expenditure does not have a significant impact on poverty in spite of their have a good governance. Seen from the probability value of these two variables are each of 0.1640 and 0.6429 (greater than 5\%).

The estimation results of the model 3 explain the effect of a given variable infrastructure budget on poverty with the control factor of the index of good governance, local revenue, gross regional domestic product, and population. Evaluation is based on criteria of statistical models seen through the value R-square or is equal to 0.967486 . This means that the variables in this model have a variable degree of appropriateness in explaining poverty by $96 \%$, While the rest can be explained by other factors outside variables. Then the probability value or F-statistics 0.0000 valued at less than 0.05 or $\alpha=5 \%$, explaining that the reliability of this model is $95 \%$.

Testing of each independent variable statistics shows that education infrastructure budget has a real effect on poverty levels. With a coefficient value of -0.084052 and probability value of less than significant level of 5 percent indicates that the educational infrastructure budget variables significantly affect poverty. Any increase in education infrastructure budget of $1 \%$, will reduce poverty by $0084 \%$. While the health and road infrastructure budget no real effect on poverty. Seen from a probability value respectively 0.1028 and 0.8419 which means greater than the level of 5 percent indicating that both the infrastructure budget does not significantly affect poverty.

The results of the fixed effect regression on the effect of infrastructure expenditure for education on the poverty line with what was conveyed by some previous researchers like Fan, Jitsuchon, and Methakunnavut (2004); Fan, Hael, Thorat (2000); Fan, Zhang and Zhang (2002); and Prasetya et al (2012). While for the effect of the health infrastructure expenditure is not aligned. Fan, Jitsuchon, and Methakunnavut (2004) studied in Thailand about the relationship between expenditure for education and poverty. The result is that by increasing one million Baths for infrastructure expenditure on education, the number of poor people would be reduced by 21. In 2000 in India, Fan, Hazel and Thorat prove that each issuing of one million rupees for the expenses of education and health infrastructure, so each community will pull out of the poverty line by 41 people and 18 people. Then the study conducted by Fan, Zhang, and Zhang in 2002 in China, yielded that every government expenditure on the educational infrastructure of 10,000 yuan, so as many as nine people would be out of poverty.

The allocation of the educational and health infrastructure budget actually aims to increase the level of human life and increase the quality of human resources to become productive human beings. Education infrastructure expenditure as stated in Presidential Decree No. 122 of 2016, namely as a means of learning provision; laboratory; training center; research centers or study centers; infrastructure research and development; student practice room; libraries and learning support and training facilities. Isjoni (2006) states that 
the availability of facilities and infrastructure to support the learning process will greatly influence the quality of education. The construction of classrooms worth going to create a learning atmosphere that is comfortable, the library will adequately support the improvement of the quality of education as well as the laboratory will provide access to knowledge, improving the quality of education and improving the science will ultimately have an impact on the creation of productive human. While for the effect of the health infrastructure expenditure is not aligned.

Such as education, infrastructure expenditure for health also aim to provide and improve the quality of health infrastructure. As is well known that health is one of the factors that affect human resources. Malnutrition or a low level of public health will result in low quality of man with mental retarded level. Thus, expenditure on health infrastructure is very useful in order to fulfill one of the basic right to obtain medical care in the form of facilities and services that are a precondition for increasing the productivity of society (Todaro and Smith, 2003). However, in this study for health infrastructure expenditure does not have a significant impact on poverty reduction. Or it can be explained that with the issuance of highspending health infrastructure can not accommodate the circumstances of the poor. This can occur where a number of the budget spent not on target. This means that the budget has been used for other purposes that have nothing to do with direct service delivery to the poor. Such as non-poor communities get the facilities that are supposed to be for the poor.

Other problems can also occur where poor people have less gain more attention in the service due to the policies or the flow of health care procedures cumbersome, especially for the poor. So that medical authorities discriminate ministry among the poor with other patients who pay higher medical fees in cash. An example is when poor people first come to the hospital to get health facilities, the poor tend to wait too long for service than the wealthy community. Another example is when the poor get access inpatient services by the poor card given by the government, likely to be given a short time, which is usually only for one week only. Whereas other patients who paid with private money was never in limiting the duration to get the service, and the price of health care each year could turn out to be higher depending on the prevailing price. So with the high budget spent poverty is also higher.

Infrastructure expenditure for roads in Indonesia does not have a significant impact on poverty reduction. These results reject the theory of Fan, Zhang, and Zhang (2002) in China, which states that an increase of 10,000 Yuan for spending on good and high-quality road infrastructure can lift 3.2 poor people into the poverty line because it connects major industrial centers with rural roads. There are two conclusions to be drawn from the results of this regression. First, that the high expenditure on road infrastructure due to building roads in rural areas and disadvantaged with a high poverty rate. So that higher expenditure is not able to have an impact on poverty reduction. This can be seen through the figure 1 , that the trend for road infrastructure budget has fluctuated. There is no continuous increase every year, and the proportion of the budget spent is higher in rural areas than in urban areas.

Second, expenditure for road infrastructure cannot reduce poverty because through this expenditure, the roads built cannot be fully enjoyed by the poor. As we know that over the years, the higher of infrastructure expenditure on roads has been used to built and improve the motorway. While toll roads can only be passed by using 4 wheeled vehicles and more so this facility can be enjoyed by the rich. This agrees with Prawesti and Hermawan (2017) in their research on infrastructure development and poverty reduction in Java. Their result suggests by the fact that the rich people than the poor people utilize the transportation system more effectively. The higher the access road makes entrepreneurs can build a few stores in rural causing loss of income of poor people. In other words, road access in rural areas is not used by the poor to access the economic market. But more used to seek education or health so that the road does not contribute to reducing poverty. Whereas this facility should be used by the poor optimally to reach the market economy. Such as what was delivered by Hastuti (2016) that the more extensive the quality road will be the higher the chances of society to improve the economy. Therefore, the expenditure of health infrastructure does not significantly affect poverty even though local revenue and regional gross regional domestic product increases. 
Another factor that can explain the impact of infrastructure expenditure on poverty is the index of good governance. Means that in order to reduce the poverty rate, both the infrastructure expenditure for education, health, and the road must be through good governance. Because the budget for development issues is the issue of how the government can use it effectively and efficiently, and use the right target. As the theory advanced by Turkewitz (2001) and Rajkumar, Swaroop (2002) that the better governance of the budget for infrastructure development carried out, it will be the exact function of the budget is allocated so that the objectives of infrastructure expenditure can be achieved.

This paper proves that there is an effect of good governance to poverty reduction. The higher the index of good governance, the lower the number of poverty. While the index of good governance in Indonesia is still relatively low, causing the allocation function of infrastructure expenditure cannot reduce the poverty that is so big. One of the causes due to lack of accountability of local governments in realizing the entire budget that has been determined. This is evident through research conducted by Arma (2016) who examines the financial health of the region. It was found that there are still many districts and cities in Indonesia during 2006 to 2013 whose financial status is unhealthy due to low budget absorption.

The low budget absorption will have an impact on the not realizable of budget planning. One of them can happen in the development of education, health and road infrastructure. Thus, not fully realized will result in ineffective expenditure on infrastructure to reduce poverty. Therefore, there is a need for good governance to manage infrastructure budgets. The existence of good governance, budget absorption for poverty alleviation program can run optimally.

\section{CONCLUSION}

This paper has analyzed the relationship posed by infrastructure expenditure for education, health, and the road to poverty reduction in Indonesia using the control variables of income, regional gross domestic product, population and good governance index. Based on the District and State level in Indonesia, were analyzed using a fixed effect method generates that infrastructure expenditure for education that is directed through increased local revenues, gross regional domestic product and indices of good governance have a significant negative effect but inelastic with respect to poverty reduction. As for the health and road infrastructure expenditure showed no effect on poverty reduction for health care does not fully pro-poor and more road construction majority enjoyed by the rich.

\section{APPENDIX}

Table A1 - The Result of Fixed effect Regression on Poverty

\begin{tabular}{|c|c|c|c|c|c|c|}
\hline \multirow{2}{*}{ Variable } & \multicolumn{2}{|c|}{ Model 1} & \multicolumn{2}{|c|}{ Model 2} & \multicolumn{2}{|c|}{ Model 3} \\
\hline & Coef. & Prob. & Coef. & Prob. & Coef. & Prob. \\
\hline Inf. Ex. Education & -0.084824 & 0.0000 & -0.081445 & 0.0000 & -0.084052 & 0.0000 \\
\hline Inf. Ex. Health & -0.015355 & 0.1430 & -0.014582 & 0.1640 & -0.016581 & 0.1028 \\
\hline Inf. Ex. Roads & 0.005943 & 0.6510 & 0.006086 & 0.6429 & 0.002426 & 0.8419 \\
\hline GGI & & & -1.551870 & 0.0078 & -0.698453 & 0.2150 \\
\hline PAD & & & & & -2.247482 & 0.1403 \\
\hline GDP & & & & & -6.717167 & 0.0003 \\
\hline TP & & & & & 135.8329 & 0.0000 \\
\hline R-Squared & \multicolumn{2}{|c|}{0.961647} & \multicolumn{2}{|c|}{0.961675} & \multicolumn{2}{|c|}{0.967486} \\
\hline Adjusted R-squared & \multicolumn{2}{|c|}{0.956240} & \multicolumn{2}{|c|}{0.956263} & \multicolumn{2}{|c|}{0.962771} \\
\hline Prob (F-stat) & \multicolumn{2}{|c|}{0.000000} & \multicolumn{2}{|c|}{0.000000} & \multicolumn{2}{|c|}{0.000000} \\
\hline
\end{tabular}

\section{REFERENCES}

1. Ali, I dan Pernia, E.M. 2003. Infrastructure and Poverty Reduction- What is the Connection?, Philipppines: Asian Development Bank.

2. Arma, N.A. 2016. Penyerapan anggaran pemerintah daerah untuk melihat kesehatan keuangan pemerintah daerah tahun 2006-2013. Malang: Brawijaya press. 
3. Databoks. 2016. Alokasi Anggaran Infrastruktur Dalam APBN 2010-2016, Online. Accessed through http://databoks.katadata.co.id/datapublish/2016/08/04/alokasianggaran-infrastruktur-dalam-apbn-2010-2016 on 25 September 2017 at 20.00 pm.

4. Familioni.K.A. 2004. The role of Economic and sosial infrastructure in economic Development, A Global View.

5. Fan, S. 2000. Government spending, growth and poverty in rural India. International journal of American Agricultural Economics Association, Amer. J. Agr. Econ. 82(4): 1038-1051.

6. Fan, S. 2002. Growth, Inequality and Poverty in China; The Role of Public Investments. Research Report 125. InternationalFood Policy Research Institute, Washington D.C.

7. Fan, S. 2004. The importance of public investment for reducing rural poverty in middleincome countries: the case of Thailand. DSGD Discussion paper No.7, International Food Policy Research Institue, 2033 K Street, N.W. Washington, D.C.

8. Gupta, Davoodi \& Tiongson. 2000. Corruption and a provision of health care and education services. IMF working paper No. 00/116, June, International monetary fund, Washington DC.

9. Hastuti, A. T. 2016. Analisis Kemiskinan dan Ketersediaan Infrastruktur di Pedesaan kawasan jalan lintas selatan jawa timur, Malang: Universitas Brawijaya.

10. Isjoni. 2006. Membangun Visi Bersama : Aspek-Aspek Penting dalam Reformasi Pendidikan. Jakarta :Yayasan Obor Indonesia

11. Jhinghan, M.L. 2000. Ekonomi pembangunan dan perencanaan. Jakarta: Raja grafindo persada.

12. Kartasasmita, G. 1996. Pembangunan Untuk Rakyat; Memadukan Pertumbuhan dan Pemerataan, Jakarta: CIDES.

13. Kaufmann, D., Kraay, A., Zoido-Lobaton, P., 1999. Governance matters. World Bank, Development Economics Research Group, Washington, D.C.

14. Kuncoro, M. 2010. Dasar-Dasar Ekonomika Pembangunan. Yogyakarta: UPP STIM YKPN Yogyakarta.

15. Mardiasmo. 2005. Akuntansi Sektor publik, Yogyakarta: Penerbit Andi.

16. Marinho, E. et al. 2017. Journal EconomiA. Impact of Infrastructure Expenses in Strategic Sectors for Brazilian Poverty, Vol18(2017) 244-259. Elsevier Publishing.

17. Prasetiya F \& WP Farah.2012. Linkages Between Public Sector Expenditure On Economic Growth And Rural Poverty Of Indonesia. ISSN 2090-4304 Journal of Basic and Applied Scientific Research.

18. Prawesti, P.A \& Hermawan, R. 2017. Infrastructural development and poverty reduction in Java, Indonesia 2002-2012. JPAS Vol.1, No. 3, pp, 71-79.

19. Rajkumar, A.S, \& Swaroop, V. 2008. Public spending and outcomes: Does governance matter?. Journal of development economics 86 (2008) 96-111.

20. Roser, M., \& Ospina, E.O. 2018. Global Extreme Poverty. Publish online at OurWorldlnData.org.

21. Runsinarith, P. 2010. Infrastructure and Poverty Reduction: Evidence from Cambodia's Border Provinces, Cambodia: Nagoya University.

22. Rustanto, B. 2015. Menangani kemiskinani. Bandung: PT Remaja Rosdakarya.

23. Seetanah, 2009. International Journal of Applied Economitrics and Quantitative Studies. Does Infrastructure Alleviates Poverty in developing Countries?, V6-2.

24. Solihin, D. 2014. Implementasi Kebijakan Pengentasan Kemiskinan. Jakarta: Yayasan empat sembilan Indonesia.

25. Sumarto, S., et. al,. 2004. Tata kelola pemerintah dan penanggulangan kemiskinan: Bukti-bukti awal desentralisasi di Indonesia. Lembaga peneliti SMERU.

26. Todaro,M.P., Smith, S.C. 2011. Pembangunan ekonomi. Jakarta: erlangga.

27. Turkewitz. 2001. "Summary of Procedings on Training of Trainers Program on Public Expenditure Management". Tokyo.

28. World Bank. 1994. World Development Report: Infrasrtucture for Development. UK: Oxford University Press Inc.

29. World Bank (2004) Indonesia Policy Briefs-ide-ide 100 hari, Mengurangi kemiskinan, accessed through http://siteresources.worldbank.org/ 